\title{
Habitat heterogeneity on feeding habit of two sympatric and congeneric characidae fishes in two tropical reservoirs
}

\author{
Vanessa G. Lopes' ${ }^{1}$ Jorge L. Nessimian², Elidiomar R. Da-Silva ${ }^{3}$, José Henrique C. Gomes, \\ Ana Carolina I. M. Dias' ${ }^{5}$ Leonardo C. Souza ${ }^{3} \&$ Christina W.C. Branco 3
}

\begin{abstract}
1. Departamento de Biologia Geral, Instituto de Ciências Biológicas, Universidade Federal de Goiás, UFG, 74001-970 Goiânia, GO, Brazil. (vglopes@gmail.com) 2. Laboratório de Entomologia, Departamento de Zoologia, Instituto de Biologia, Universidade Federal do Rio de Janeiro, UFRJ, Av. Carlos Chagas Filho 373 , Cidade Universitária, 21971-902, Rio de Janeiro, RJ, Brazil. (jnessimian@gmail.com)

3. Departamento de Zoologia, Instituto de Biociências. Universidade Federal do Estado do Rio de Janeiro, UNIRIO, Av. Pasteur 458, Urca, 22290-040

Rio de Janeiro, RJ, Brazil. (elidiomar@gmail.com, coimbral@gmail.com, cbranco@unirio.br)

4. Transpetro - Petrobras Transporte S.A., Av. Presidente Vargas 328, Centro, 20091-060 Rio de Janeiro, Brazil. (jhcgomes2@gmail.com)

5. Fiperj - Fundação Instituto de Pesca do Estado do Rio de Janeiro, Diretoria de Pesquisa e Produção, Praça Fonseca Ramos s/n, sobreloja, Centro,

24030-020, Niterói, RJ, Brazil. (anacaroliozzi@gmail.com)
\end{abstract}

Received 03 March 2015

Accepted 01 June 2016

DOI: 10.1590/1678-4766e2016012

\begin{abstract}
Food flexibility and omnivory are important features pronounced in Neotropical freshwater fish species, particularly for Astyanax species. Traditionally most fish diet resources are known to be originated in the aquatic environment, however recent studies have pointed to the importance of allochthonous sources. Besides, the colonization of macrophytes, common at several tropical reservoirs, may enhance insectivory in fish diet expanding or concentrating the area of available resources for feeding. Here we employed stomach contents analysis of two sympatric Astyanax species to access the importance of habitat differentiations as spatial complexity in two tropical reservoirs with different environmental features. The NMDS analysis indicated separation in the diet of these species between reservoirs (Stress $=8.28 \%$ ). Additionally, analysis of variance revealed a significative difference in the volume of food itens ingested between the reservoirs (Anova one-way $F(1,132)=4.4446 ; p=0.037$ ). This points out the importance of environmental conditions on the composition of the diet of fishes. This study highlighted the insectivorous feeding habit of Astyanax species and revealed different feeding strategies between sympatric fishes despite high niche overlap in both environments. Habitat heterogeneity increasing food resources availability plays an important role in the diet strategy of these Astyanax species and on their constant maintenance in the two different reservoirs.
\end{abstract}

KEYWORDS. Feeding resources, land-water ecotone, trophic ecology, Astyanax aff. bimaculatus, Astyanax parahybae.

RESUMO. Heterogeneidade de habitat no hábito alimentar de duas espécies simpátricas e congenéricas de peixes caracídeos em dois reservatórios tropicais. A flexibilidade alimentar e onivoria são características das espécies de peixes de água doce neotropicais, especialmente em espécies de Astyanax. Tradicionalmente a maioria dos recursos na dieta de peixes é reconhecidamente originária do ambiente aquático, porém estudos recentes têm apontado para a importância das fontes alóctones. Além disso, a colonização de macrófitas, comuns em vários reservatórios tropicais, pode melhorar os aspectos de insetivoria na dieta dos peixes expandindo ou concentrando a área disponível para a alimentação. Aqui analisamos o conteúdo estomacal de duas espécies de Astyanax simpátricas para avaliar a importância das diferenças de habitats, como a complexidade espacial, em dois reservatórios tropicais com diferentes características ambientais. A análise NMDS indicou separação na dieta destas espécies entre reservatórios (stress $=8.28 \%$ ). Além disso, a análise de variância revelou uma diferença significativa no volume de itens alimentares consumidos entre os reservatórios (Anova one-way F (1. $132)=4,4446 ; \mathrm{p}=0.037)$, salientando a importância das condições ambientais na composição da dieta de peixes. O estudo destacou o hábito alimentar insetívoro das espécies de Astyanax e revelou diferentes estratégias de alimentação entre esses peixes simpátricos apesar da alta sobreposição de nicho nos dois ambientes. A heterogeneidade de hábitat aumentando a disponibilidade de recursos alimentares teve importância sobre a estratégia alimentar das espécies de Astyanax e consequentemente na manutenção constante de ambas nos dois diferentes reservatórios.

PALAVRAS-CHAVE. Recursos alimentares, ecótono terra-água, Ecologia trófica, Astyanax aff. bimaculatus, Astyanax parahybae.

Trophic interactions and quantifying spatial and temporal variability in fish diet remains a challenge for ecologists (SCHEFFER \& CARPENTER, 2003; MCCANN et al., 2005). Food flexibility and omnivory are important features particularly pronounced in Neotropical freshwater fish species (LOWE-MCCONNELL, 1999; GONZÁLEZ-BERGONZONI et al., 2012). The food variety in the tropics can be associated with environmental conditions of the aquatic ecosystem. May be influenced directly by characteristics of land, vegetation, human activities in the drainage systems and the driving forces of dry and rainy period (MANNA et al., 2012; XU et $a l ., 2012)$. Furthermore, the fish capacity to explore this broad food supply is directly connected with the biology of species (ABELHA et al., 2001). 
Astyanax Baird \& Girard, 1854 species are known to be highly flexible in their diets and reported as omnivorous species (VILELla et al., 2002; Dias et al., 2005; ManNa et al., 2012). Feeding habits of several Astyanax species have been well studied in different Brazilian aquatic ecosystems such as in streams and rivers (VILELLA et al., 2002; LOUREIRO-CRIPPA \& HAHN, 2006; Borba et al., 2008; VIDOTTO-MAGNONI \& Carvalho, 2009; Manna et al., 2012; Moraes et al., 2013), floodplain (Esteves, 1996, Peretti \& Andrian, 2004, 2008; CrIPPA et al., 2009) and coastal lagoons (HARTZ et al., 1996; Aguiaro \& Caramaschi, 1998). Besides feeding plasticity (SANTOS et al., 2008), the proliferation of some species of Astyanax, especially A.bimaculatus and A. parahybae, in reservoirs has been associated with their reproductive strategy, including a long reproductive period, rapid maturation, prolific spawning, small eggs and high fecundity (SuzuKi et al., 2005). Astyanax species have also a great ecological importance in the trophic web of fish community in reservoirs (LOUREIRO-CRIPPA \& HAHN, 2006; WoLfF et al., 2009) linking nutrients and carbon sources available in marginal areas to the limnetic food chain.

Many resources sustain fish fauna in tropical reservoirs and most of them originate in the aquatic environment (ARAÚJo-Lima et al., 1995). However, morphometric features of the reservoir, such as perimeter and depth, retention time, characteristics of the area flooded and elapsed time from filling can influence the availability of the resources for fish. Recent studies have pointed to the importance of allochthonous sources for fish feeding mainly coming from marginal areas of dendritic reservoirs and with riparian forests (ARAúJo et al., 2005; Mazzoni \& Rezende, 2003; SiLva et al., 2014). Besides spatio-temporal variations in food availability strongly modulate foraging behavior (LÓPEZ-BAO et al., 2011) and seasonal variation in the quantity and also quality of the diet (JUNK, 1980) may be a consequence of the hydrological regime of reservoirs (ABELHA et al., 2001).

The colonization of macrophytes in many reservoirs may enhance aspects of invertivory in fish diet (Pelicice \& Agostinho, 2006) expanding or concentrating the area of available resources for feeding. Aquatic macrophytes are important habitats for many groups of organisms as immature stages of Diptera, Ephemeroptera and Trichoptera (CARPenter \& Lodge, 1986; Lalonde \& Downing, 1992; DibBle et al., 1996; AgostinHo et al., 2003; CASATti et al., 2003) and many fish species are found in these habitats, benefiting from a diversity of food items as well as refuge from predation (Pelicice \& Agostinho, 2006). Macrophytes have also been considered key components in aquatic environments, enhancing the spatial heterogeneity and increasing the number of niches (MARGALEF, 1983; TRIVINHOStrixino \& Strixino, 1993; SANTOS et al., 2008).

We employed stomach contents analysis to access the importance of habitat differences as spatial complexity for Astyanax feeding in two tropical reservoirs with different environmental features. This was investigated for Astyanax aff. bimaculatus Linnaeus, 1758 and Astyanax parahybae Eigenmann, 1908 (Characiformes: Characidae), which are sympatric species with frequent occurrence in both environments (GOMES et al., 2008; UeHARA et al., 2015) and similar diets. Given the differences between these reservoirs, and based on aspects mentioned above we predicted that the environment where fishes inhabit will control the composition of the diet (niche width) influencing the trophic relation between the sympatric species (niche overlap) more than seasonality.

\section{MATERIAL AND METHODS}

Study area. This study was conducted in two reservoirs belonging to the complex of electrical power company Light SA (Piraí Municipality, Rio de Janeiro State, Brazil). The Ribeirão das Lajes Reservoir (Lajes Reservoir) (22 $42^{\prime}$ $22^{\circ} 50^{\prime} \mathrm{S}, 43^{\circ} 53^{\prime}-44^{\circ} 05^{\prime} \mathrm{W}$ ) situated at $415-430 \mathrm{~m}$ above sea level, has a surface area of 30.7 to $47.8 \mathrm{~km}^{2}$ and an average depth of $15 \mathrm{~m}$ and a maximum of $40 \mathrm{~m}$ and retention time of 300 days. The reservoir presents oligo-mesotrophic waters, used for the domestic water provision of around 1.1 million people. The high water quality of the Lajes Reservoir has been associated to the presence of a rain forest in most of its surroundings and low human influence. The dendritic shape of the lake and no abrupt fluctuations in water level impose an important ecotone between the aquatic and terrestrial areas, subject to direct exploitation by aquatic fauna.

The Santana Reservoir is located 361-363 m above sea level (between $22^{\circ} 31^{\prime} 50^{\prime \prime} \mathrm{S}$ and $43^{\circ} 49^{\prime} 15^{\prime \prime} \mathrm{W}$ ). It was built in 1945 , has a surface area of approximately $5.23 \mathrm{~km}^{2}$, with an average depth of $3.3 \mathrm{~m}$ and a maximum of $12 \mathrm{~m}$ and a retention time of one day. The reservoir is considered eutrophic and is characterized by a high degree of human impact, since its waters receives drainage from urban, industrial and agricultural activities. The surroundings are covered by pasture and the continued nutrient input has resulted in the proliferation of macrophytes throughout the lake.

The climate of the region where the reservoirs lie is classified as high-altitude tropical with average temperatures of $20.5^{\circ} \mathrm{C}$ ranging from $16.6^{\circ} \mathrm{C}$ in July to $23.9^{\circ} \mathrm{C}$ in February. The months with the highest rainfall are November, December and January and the months with the least rainfall are May, June and July. The Lajes Reservoir level is maintained artificially and the highest level is reached at the end of the rainy season (April) and the lowest at the beginning of this season (November). There is no influence of seasonality on the level of the Santana Reservoir, which is managed according to operational needs and daily variations of up to 1.5 meters can occur.

Sampling. Adult fish were collected at both reservoirs in dry (May 2005, June/July 2007) and rainy (March 2004, January 2008) seasons, by means of gill-nets with mesh sizes ranging from 1.5 to $4.0 \mathrm{~cm}$. The samplings followed a previously established standardized effort in the two sites, considering the amount of nets, as well as the total hours of capture. Gill-nets were placed parallel to the shore or in closed meanders and capture time was 12 hours, from dusk to sunrise. Since fishes can modify their food habits during different 
life stages, we selected only adult individuals based on their standard length that ranges from 6.5 to $12.5 \mathrm{~cm}$ (Astyanax aff. bimaculatus) and 7.1 to $12.5 \mathrm{~cm}$ (Astyanax parahybae). The fish were weighed, measured (standard length), and killed by freezing immediately after collection. The fish stomach content was removed at the laboratory and fixed in $10 \%$ formalin. All voucher specimens were deposited in the Collection of the Museu Nacional (Universidade Federal do Rio de Janeiro - UFRJ), under the code MNRJREG20050418.

Data analysis. The stomach content analysis was performed according to methodology proposed by (WINDELL, 1971; Hyslop, 1980; Branco et al., 1997). The food items were grouped into categories [Algae, Egeria (aquatic macrophyte), Terrestrial Plant, Zooplankton, Ostracoda, Nematoda, Acarina, Aranae, Gastropoda, Aquatic Insect, Terrestrial Insect, Fish Scale, Organic Matter and Sand]. The taxonomic identification of food items was done according to appropriated literature and the insects were identified to family level. Based on the data of frequency of occurrence $(\%$ F) and volume percentage (V\%), the Alimentary Importance Index - IAi was calculated (KAWAKAMI \& VAZZOLLER, 1980) - IAi $=(\% \mathrm{~F} \mathrm{x} \% \mathrm{~V}) / \stackrel{\circ}{\mathrm{a}}(\% \mathrm{~F} x \% \mathrm{~V})$. To examine spatial patterns in fish diet, the volumes of the diet items were ordered using non-metric multidimensional scaling (NMDS) with a BrayCurtis dissimilarity index. A parametric one-way ANOVA was performed to test diet differences, also a similarity percentage analysis (SIMPER) was used to examine the contribution of each food item to the average dissimilarity between species in each reservoir. All the analyses were performed using the program R (R CORE TEAM, 2013).

Niche analysis. The niche width was calculated using the MacArthur-Levins measure (MACARTHUR \& Levins, 1967) considering $B=1 / \sum(\mathrm{Pij})^{2}$ where $\mathrm{B}=$ measure of niche breadth, and $\mathrm{Pij}=$ proportion of category item " $\mathrm{j}$ " in the diet. Breadth niche values were set at the following levels: high $(>0.6)$, intermediate $(0.4-0.6)$ or low $(<0.4)$, according to NovaKowsKi et al. (2008). Feeding overlap was measured for each reservoir using the Pianka Index (PIANKA, 1974) according to the formula $\alpha=\sum \mathrm{Pij} * \mathrm{Pik} / \sqrt{ } \sum \mathrm{Pij}^{2} * \sum \mathrm{Pik}^{2}$ where $\alpha=$ Pianka measure of niche overlap from 0 to 1, Pij, Pik $=$ proportion of item "I" used by species " $j$ " and " $k$ ".

\section{RESULTS}

We analyzed the stomach contents of sixty-five specimens of Astyanax aff. bimaculatus and seventy of $A$. parahybae. The food items were gathered in 14 food items categories shown in Tab. I. Insects and organic matter were the most important category items for both species. Some changes at the importance of some categories were found between rainy and dry seasons

The ordering produced by NMDS analysis indicated separation in the diet of these species between reservoirs (Stress= 8.28\%), and a slight influence of seasonality (Fig.1). This points out a higher importance of environment conditions in the composition of the diet of fishes than the seasonality. Additionally, analysis of variance revealed no significant differences in food items between the species studied (Anova one-way $\mathrm{F}(1,133)=1.9569, \mathrm{p}=0.164)$ and between rainy and dry seasons (Anova one-way $F=(1,132)=0.061 ; p=0.805$ ). However, we found a significative difference in the volume of food items between the reservoirs (one-way Anova F(1, 132) $=4.4446 ; \mathrm{p}=0.037$ ).

The SIMPER analysis showed which categories items were the most important in the differentiation of diets. On Lajes Reservoir, organic matter and insects, mainly terrestrial insect had greater importance for Astyanax aff. bimaculatus and aquatic insect for $A$. parahybae diet. On Santana Reservoir, organic matter and terrestrial insect were important itens for both species. The secundary items consumed by the fish were responsible for diet differences in this reservoir. Astyanax parahybae fed on algae and on aquatic and terrestrial vegetation probably near macrophytes patches. Astyanax aff. bimaculatus preyed on invertebrates associated to terrestrial vegetation, e.g., gastropods (Tab. II) showing different strategies on food acquision.

We also analyzed the niche width for both species that was considered low, between 0.17 and 0.35 , for possible values between 0 and 1 (Fig. 2). The highest value of niche width was found for Astyanax aff. bimaculatus in Santana Reservoir and the lowest for the same species in Lajes Reservoir. The niche overlap for both species was higher for Lajes Reservoir (Fig. 2).

\section{DISCUSSION}

Also classified as opportunistic species (Dias et al., 2005), Astyanax display a great ability to change their prey according to environmental variations. This study confirmed the insectivorous-omnivorous habit and feeding plasticity for both Astyanax species, as indicated by several other authors (e.g. Nomura, 1975; ArCifA et al., 1991; UiedA et al., 1997; BENNEMANn et al., 2006; ABILHOA, 2007) and also highlighted the insetivorous feeding habit, likewise displayed by other Astyanax species specially in streams and rivers (see VILELLA et al., 2002 for A. eigenmanniorum; VIDOTTO-MAGNONI \& CARVAlHo, 2009 for A. altiparanae and Ferreira et al., 2012 for A. paranae). At this context, diet dissimilarities between the Astyanax species were revealed mainly due to the source of itens consumed. Feeding strategies may differ among environments and omnivory may evolve as a response to high environmental heterogeneity (CHUBATY et al., 2014) or food availability.

Given the habitat differences between these reservoirs, different spatial complexity and presence of macrophyte patches, we expected dissimilar diet patterns. Our results showed that Astyanax aff. bimaculatus diet consisted of insects, terrestrial and aquatic insects, as well as the low consumption of zooplankton, which suggest feeding habit on the water column surface and near marginal area in both reservoirs. Meanwhile, aquatic insects and zooplankton had an inexpressive importance at Santana Reservoir diet, but algae had high significance. On the other hand, A. parahybae exhibited different preferences in each reservoir, aquatic 
Tab. I. Food items found in the diet of Astyanax aff. bimaculatus Linnaeus, 1758 and A. parahybae Eigenmann, 1908 in the Lajes (Lajes) and Santana reservoirs, state of Rio de Janeiro, Brazil in rainy and dry seasons (N, number of individuals analysed; IAi, Alimentary Importance Index; SL, range of standard length).

\begin{tabular}{|c|c|c|c|c|}
\hline \multirow{4}{*}{ Astyanax aff. bimaculatus } & \multicolumn{2}{|c|}{ LAJES } & \multicolumn{2}{|c|}{ SANTANA } \\
\hline & Rainy $(\mathrm{N}=20)$ & Dry $(\mathrm{N}=20)$ & Rainy $(\mathrm{N}=8)$ & Dry $(\mathrm{N}=17)$ \\
\hline & SL $9.5-12.5 \mathrm{~cm}$ & SL $7.5-9.9 \mathrm{~cm}$ & SL $6.9-10.5 \mathrm{~cm}$ & SL $6.5-11.5 \mathrm{~cm}$ \\
\hline & $\mathrm{IAi}$ & IAi & IAi & IAi \\
\hline Algae & 0.02 & 0.00 & 232.49 & 0.00 \\
\hline Egeria sp. & 0.00 & 0.00 & 0.00 & 24.92 \\
\hline Terrestrial plant & 0.35 & 0.03 & 9.77 & 19.26 \\
\hline Zooplankton & 16.58 & 3.36 & 0.31 & 0.00 \\
\hline Ostracoda & 0.00 & 0.05 & 0.00 & 0.00 \\
\hline Nematoda & 0.15 & 0.03 & 2.60 & 0.00 \\
\hline Acarina & 0.00 & 0.01 & 0.00 & 0.00 \\
\hline Araneae & 0.00 & 0.28 & 0.00 & 0.00 \\
\hline Gastropoda & 0.00 & 0.26 & 260.82 & 0.09 \\
\hline Aquatic insect & 510.06 & 116.81 & 0.00 & 6.18 \\
\hline Terrestrial insect & 1223.08 & 629.55 & 1489.97 & 1038.88 \\
\hline Fish scale & 0.35 & 15.97 & 0.00 & 0.00 \\
\hline Organic matter & 849.16 & 1985.36 & 245.61 & 2285.68 \\
\hline Sand & 0.00 & 0.00 & 0.00 & 0.23 \\
\hline & Rainy $(\mathrm{N}=6)$ & Dry $(\mathrm{N}=25)$ & Rainy $(\mathrm{N}=14)$ & Dry $(\mathrm{N}=25)$ \\
\hline Astyanax parahybae & SL $10.5-12 \mathrm{~cm}$ & SL $7.5-12.5 \mathrm{~cm}$ & SL $7.1-9.0 \mathrm{~cm}$ & SL $7.5-10.5 \mathrm{~cm}$ \\
\hline & $\mathrm{IAi}$ & $\mathrm{IAi}$ & $\mathrm{IAi}$ & IAi \\
\hline Algae & 0.00 & 0.00 & 729.77 & 111.09 \\
\hline Egeria sp. & 0.00 & 0.00 & 351.30 & 16.43 \\
\hline Terrestrial plant & 0.00 & 0.29 & 0.00 & 192.10 \\
\hline Zooplankton & 0.00 & 23.17 & 0.00 & 0.08 \\
\hline Ostracoda & 0.00 & 0.01 & 0.02 & 0.00 \\
\hline Nematoda & 0.00 & 0.68 & 0.13 & 0.00 \\
\hline Acarina & 0.00 & 7.48 & 0.01 & 0.00 \\
\hline Araneae & 0.41 & 0.14 & 0.00 & 0.00 \\
\hline Aquatic insect & 2498.53 & 1717.18 & 36.66 & 11.07 \\
\hline Terrestrial insect & 713.07 & 0.00 & 300.49 & 944.44 \\
\hline Fish scale & 0.00 & 0.30 & 0.39 & 0.06 \\
\hline Organic matter & 214.68 & 1710.78 & 298.01 & 1032.37 \\
\hline
\end{tabular}

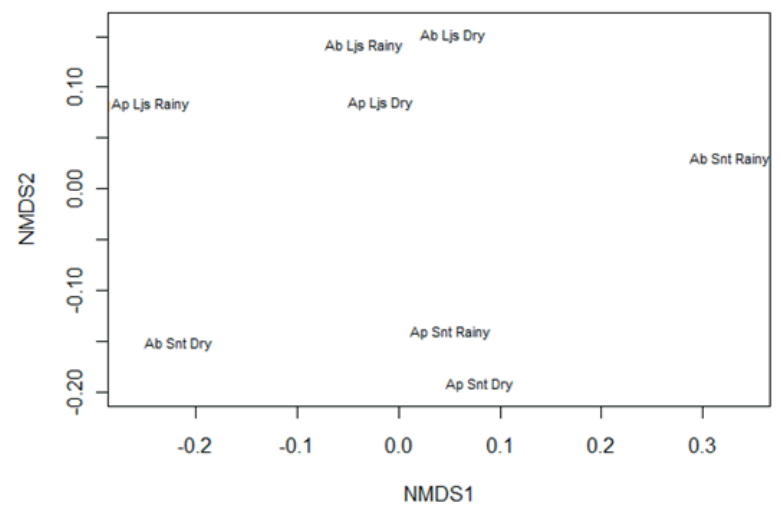

Fig. 1. NMDS plot showing relation of food item abundance found in the diet of Astyanax aff. bimaculatus Linnaeus, 1758 and A. parahybae Eigenmann, 1908 in Lajes and Santana reservoirs, state of rio de Janeiro, Brazil (Ap, Astyanax parahybae; Ab, Astyanax aff. bimaculatus; Ljs, Lajes; Snt, Santana).

insects at Lajes Reservoir and terrestrial insects at Santana Reservoir. Besides, A. parahybae exhibited high consume of algae and macrophytes (Egeria) in this last reservoir. As exposed by others studies, environmental conditions showed great importance in the composition of the diet of fishes (ArCiFA \& Meschiatti, 1993; CALlisto et al., 2002; LuZ-Agostinho et al., 2006; Hahn \& Fugi, 2007).
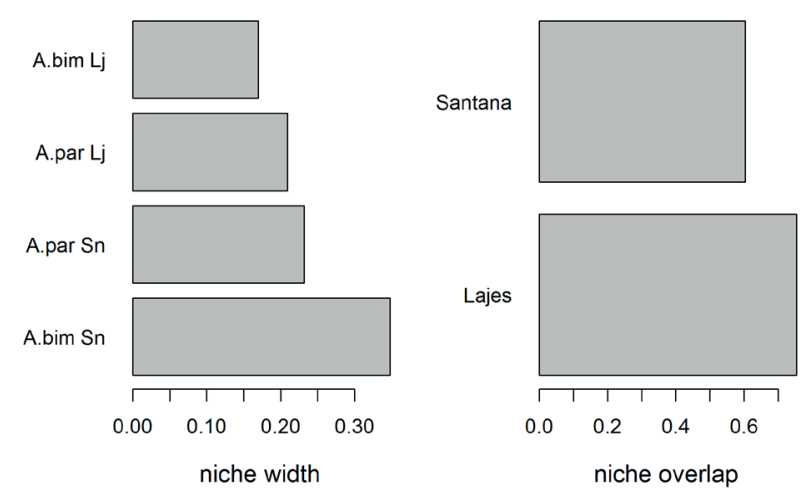

Fig. 2. Niche width and overlap of the two species in the two reservoirs, state of Rio de Janeiro, Brazil (A.bim, Astyanax aff. Bimaculatus; A.par, Astyanax parahybae; Lj, Lajes Reservoir; Sn, Santana Reservoir).

The diet of Astyanax aff. bimaculatus in the environment with less impacted surrounding vegetation (Lajes Reservoir) showed that the individuals consumed a large proportion of allochtonous items, especially insects. This high consumption of allochthonous items must be associated with preserved surrounding vegetation, essential for the input of several items in the aquatic environment 
Tab. II. SIMPER analyses of item category contributing to differences in Astyanax aff. bimaculatus Linnaeus, 1758 and A. parahybae Eigenmann, 1908 diet structure in each reservoir, State of Rio de Janeiro, Brazil.

\begin{tabular}{|c|c|c|c|c|}
\hline \multirow{2}{*}{ Reservoir } & \multirow{2}{*}{ Item } & \multicolumn{2}{|c|}{ Mean volume $\left(\mathrm{mm}^{3}\right)$} & \multirow{2}{*}{ Cumulative contribution ( $\%)$} \\
\hline & & Astyanax aff. bimaculatus & Astyanax parahybae & \\
\hline \multicolumn{5}{|c|}{ (2) } \\
\hline & Organic matter & 135.94 & 95.10 & 34 \\
\hline & Aquatic insect & 87.97 & 168.00 & 67 \\
\hline & Terrestrial insect & 96.72 & 24.19 & 95 \\
\hline \multicolumn{5}{|l|}{ Santana } \\
\hline & Organic matter & 151.72 & 179.43 & 33 \\
\hline & Algae & 13.33 & 96.21 & 74 \\
\hline & Egeria sp. & 7.80 & 45.79 & 86 \\
\hline & Terrestrial plant & 11.84 & 42.17 & 93 \\
\hline & Gastropoda & 25.00 & 0.00 & 98 \\
\hline
\end{tabular}

by rain, wind or simply falling into the water. Astyanax parahybae diet, also at Lajes reservoir, is more focused on autochthonous items such as aquatic insects. Besides the contribution of allochthonous items, riparian vegetation also provides the permanence of aquatic insect larvae that feed, directly or indirectly, on allochthonous organic material imported from riparian vegetation (CASTRO, 1999; ABILHOA, 2007). This may emphasize the importance of ecotone landwater zone for fish forraging behavior ( DiAs et al., 2005; Barreto \& Aranha, 2006; CASATti, 2010).

Dropping the riparian vegetation, as found in Santana Reservoir, would lead to a reduction of allochthonous resources. However, Astyanax aff. bimaculatus and $A$. parahybae diets revealed ingestion of large amounts of allochthonous items, such as terrestrial insects in this reservoir. Besides, we found a great proportion of algae, macrophytes and gastropods in fish diets in such reservoir. The presence of macrophytes patches apparently enhances the diversity and richness of animal groups at littoral zone and interfering with the dynamics of communities at the lake ecosystem as a whole (MARGalef, 1983; Trivinho-Strixino \& Strixino, 1993; Duncan \& Kubecka, 1995; Peiró \& Alves, 2006; Vidotto-Magnoni \& Carvalho, 2009). For example, Ephemeroptera, the order of insects most consumed by $A$. parahybae in this reservoir, according to CASATTI et al. (2003) can be associated to aquatic macrophytes. Thus, we can infer that the macrophytes pacthes probably influences the items used by Astyanax species at Santana Reservoir, even as the operational actions with daily level variations (Gomes et al., 2008) that enhance the input of allochtonous items at fishes diet (ABUJANRA et al., 2009).

Our results revelead similarities between Astyanax species food resources. The niche overlap can be considered high for both environments, which would be associated with the high abundance of the same resources. Despite the availability of resources was not measured in the present study, we assume that the preyed items were abundant based in high dominance by few resources (NovakOwsKi et al., 2008). Other factors such as the combination of different microhabitats, periods of activity and strategies of foraging can allow coexistence when species present high niche overlap. This resource sharing represent a situation commonly found in tropical streams (ARANHa et al., 1998; CASATTI, 2002). A previous study at Lajes Reservoir also revealed high trophic niche overlap of Astyanax species and suggested ecomorphological differences as a way to probably decrease competition (SiLVA-CAMACHO et al., 2014).

Although the two species of Astyanax had have a high niche overlap, $A$. aff. bimaculatus showed a narrow niche breath at Lajes Reservoir. These findings may indicate that A. aff. bimaculatus are better adapted to lentic environments (Silva-CAmacho et al., 2014). Also, this can show some strategy to avoid diret competition between these species at Lajes Reservoir. On Santana Reservoir, an extremely variable flood system under more antropic influence, they had to explore different habitat and feeding resources resulting in a wider niche breath. Besides the similar basic diet for these two species and high niche overlap, they drew a slight different diet for both reservoirs. These findings corroborate the importance of trophic plasticity in Astyanax species leading to a reduced competition in these environments (AraúJo-Lima et al., 1995).

In conclusion, this study showed that these sympatric fishes despite presenting a similar diet can coexist with a low feeding competition over the reservoirs studied. Whether competition for food occurs, it is minimized by trophic plasticity and spatial segregation. Habitat heterogeneity plays an important role on food resource consumed by these Astyanax species. However, further studies are needed to allow the detection of possible changes over time, mainly to explore temporal effects of anthropogenic habitat modifications, as frequently found at reservoir environments.

Acknowledgements. We are grateful to Light Energia S.A. for financial and logistic support for collecting specimens in Ribeirão das Lajes and Santana reservoirs. We also thank to Fundação de Amparo à Pesquisa do Estado do Rio de Janeiro (FAPERJ/IC scholarship to VGL - E26/150.318/2001).

\section{REFERENCES}

Abelha, M. C. F.; Agostinho, A. A. \& Goulart, E. 2001. Plasticidade trófica em peixes de água doce. Acta Scientiarum, Biological Sciences 23(2):425-434.

ABIlHOA, V. 2007. Aspectos da história natural de Astyanax scabripinnis Jenyns (Teleostei, Charcidae) em um riacho de floresta com araucária no sul do Brasil. Revista Brasileira de Zoologia 24(4):997-1005. 
Abujanra, F.; Agostinho, A. A. \& Hahn, N. S. 2009. Effects of the flood regime on the body condition of fish of different trophic guilds in the Upper Paraná River floodplain, Brazil. Brazilian Journal of Biology 69(2 Suppl):469-479.

Agostinho, A. A.; Gomes, L. C. \& Julio, H. F. J. 2003. Relações entre macrófitas aquáticas e fauna de peixes. In: Thomaz, S. M. \& BINI, L. M. eds. Ecologia e Manejo de Macrófitas Aquáticas. Maringá, EDUEM, p. 261-279.

Aguiaro, T. \& Caramaschi, E. P. 1998. Trophic guilds in fish assemblages in three coastal lagoons of Rio de Janeiro State (Brazil). Verhandlungen des Internationalen Verein Limnologie 26(5):2166-2169.

Aranha, J. M. R.; Takeuti, D. F. \& Yoshimura, T. M. 1998. Habitat use and food partitioning of the fishes in a coastal stream of Atlantic Forest, Brazil. Revista de Biologia Tropical 46(4):951-959.

Araújo, F. G.; Andrade, C. C.; Santos, R. N.; Santos, A. F. G. N. \& Santos, L. N. 2005. Spatial and seasonal changes in the diet of Oligosarcus hepsetus (Characiformes, Characidae) in a Brazilian reservoir. Brazilian Journal of Biology 65(1):1-8.

Araújo-Lima, C. A. R. M.; Agostinho, A. A. \& Fabré, N. N. 1995. Trophic aspects of fish communities in brazilian rivers and reservoirs. In: Tundisi, J. G.; Bicudo, C. E. M. \& Matsumura-Tundisi, T. eds. Limnology in Brazil. Rio de Janeiro, ABC/SBL, p. 105-136.

Arcifa, M. S. \& Meschiatti, A. J. 1993. Distribution and feeding ecology of fishes in a reservoir: Lake Monte Alegre. Interciencia 6:257-268.

Arcifa, M. S.; Northcotet, T. G. \& Froehlich, O. 1991. Interactive ecology of two cohabiting characin fishes (Astyanax fasciatus and Astyanax bimaculatus) in an eutrophic Brazilian reservoir. Journal of Tropical Ecology 7(2):257-268.

Barreto, A. P. \& Aranha, J. M. R. 2006. Alimentação de quatro espécies de Characiformes de um riacho da Floresta Atlântica, Guaraqueçaba, Paraná, Brasil. Revista Brasileira de Zoologia 23(3):779-788.

Bennemann, S. T.; Casatti, L. \& Oliveira, D. C. De. 2006. Alimentação de peixes: proposta para análise de itens registrados em conteúdos gástricos. Biota Neotropica 6(2):1-8.

Borba, C. Da S.; Fugi, R.; Agostinho, A. A. \& Novakowski, G. C. 2008. Dieta de Astyanax asuncionensis (Characiformes, Characidae), em riachos da bacia do rio Cuiabá, Estado do Mato Grosso. Acta Scientiarum, Biological Sciences 30(1):39-45.

Branco, C. W. C.; Aguiaro, T.; Esteves, F. A. \& Caramaschi, E. P. 1997. Food sources of the Teleost Eucinostomus argenteus in two tropical coastal lagoons of Brazil. Studies of Neotropical Fauna and Environment 32:33-40.

Callisto, M.; Vono, V.; Barbosa, F. A. R. \& Santeiro, S. M. 2002. Chironomidae as a food resource for Leporinus amblyrhynchus (Teleostei: Characiformes) and Pimelodus maculatus (Teleostei: Siluriformes) in a Brazilian reservoir. Lundiana 3(1):67-73.

CARPEnter, S. R. \& Lodge, D. M. 1986. Effects of submersed macrophytes on ecosystem processes. Aquatic Botany 26(C):341-370.

CASATti, L. 2002. Alimentação dos peixes em um riacho do parque estadual Morro do Diabo, Bacia do Alto Rio Paraná, Sudeste do Brasil. Biota Neotropica 2(2):1-14.

2010. Alterações no Código Florestal Brasileiro: impactos potenciais sobre a ictiofauna. Biota Neotropica 10(4):31-34.

Casatti, L.; Mendes, H. F. \& Ferreira, K. M. 2003. Aquatic macrophytes as feeding site for small fishes in the Rosana Reservoir, Paranapanema River, Southeastern Brazil. Brazilian Journal of Biology 63(2):213222.

Castro, R. M. C. 1999. Evolução da ictiofauna de riachos sul-americanos: padrões gerais e possíveis processos causais. In: CARAMASCHI, E. P.; Mazzoni, R. \& Peres-Neto, P. R. eds. Ecologia de peixes de riachos. Rio de Janeiro, PPGE-UFRJ. Série Oecologia, p. 139-155.

Chubaty, A. M.; Ma, B. O.; Stein, R. W.; Gillespie, D. R.; Henry, L. M.; Phelan, C.; Palsson, E.; Simon, F. W. \& Roitberg, B. D. 2014. On the evolution of omnivory in a community context. Ecology and Evolution 4(3):251-265.

Crippa, V. E. L.; Hahn, N. S. \& Fugi, R. 2009. Food resource used by small-sized fish in macrophyte patches in ponds of the upper Paraná river floodplain. Acta Scientiarum, Biological Sciences 31(2):119-125.

Dias, A. C. M. I.; Castelo Branco, C. W. \& Lopes, V. G. 2005. Estudo da dieta natural de peixes no reservatório de Ribeirão das Lajes, Rio de Janeiro, Brasil. Acta Scientiarum, Biological Sciences 27(4):355-364.
Dibble, E. D.; Killgore, K. J. \& Dick, G. O. 1996. Measurement of plant architecture in seven aquatic plants. Journal of Freshwater Ecology 11:311-318.

DunCAN, A. \& KuBECKA, J. 1995. Land / water ecotone effects in reservoirs on the fish fauna. Hydrobiologia 303:11-30.

Esteves, K. E. 1996. Feeding ecology of three Astyanax species (Characidae, Tetragonopterinae) from a floodplain lake of Mogi-Guaçú River, Paraná River Basin, Brazil. Environmental Biology of Fishes 46:83-101.

Ferreira, A.; Gerhard, P. \& Cyrino, J. E. P. 2012. Diet of Astyanax paranae (Characidae) in streams with different riparian land covers in the Passa-Cinco River basin, southeastern Brazil. Iheringia, Série Zoologia 102(1):80-87.

Gomes, J. H. C.; Dias, A. C. M. I. \& Castelo Branco, C. W. 2008. Fish assemblage composition in three reservoirs in the State of Rio de Janeiro. Acta Limnologica Brasiliensia 20(4):373-380.

GonzÁlez-Bergonzoni, I.; MeErhofF, M.; Davidson, T. A.; TeIXeIra-DEMello, F.; BaAtTrup-Pedersen, A. \& JepPesen, E. 2012. Meta-analysis Shows a Consistent and Strong Latitudinal Pattern in Fish Omnivory Across Ecosystems. Ecosystems 15(3):492-503.

Hahn, N. S. \& Fugi, R. 2007. Alimentação de peixes em reservatórios brasileiros: alterações e conseqüências nos estágios iniciais do represamento. Oecologia Brasiliensis 11(4):469-480.

Hartz, S. M.; Silveira, C. M. \& Barbieri, G. 1996. Alimentação das espécies de Astyanax Baird \& GIRARD, 1854 ocorrentes na lagoa Caconde, RS, Brasil (Teleostei, Characidae). Revista Unimar 18(2):269-281.

HysLOP, E. J. 1980. Stomach contents analysis - a review of methods and their application. Journal of Fish Biology 17:411-429.

JunK, W. J. 1980. Áreas inundáveis - Um desafio para Limnologia. Acta Amazonica 10(4):775-795.

KaWAKami, E. \& Vazzoller, G. 1980. Método gráfico e estimativa de índice alimentar aplicado no estudo de alimentação de peixes. Boletim do Instituto Oceanográfico 29(2):205-207.

LAlonde, S. \& Downing, J. A. 1992. Phytofauna of eleven macrophyte beds of differing trophic status, depth, and composition. Canadian Journal of Fisheries and Aquatic Sciences 49:992-1000.

López-Bao, J. V.; Palomares, F.; Rodríguez, A. \& Ferreras, P. 2011. Intraspecific interference influences the use of prey hotspots. Oikos 120(10):1489-1496.

Loureiro-CripPa, V. E. \& HAHN, N. S. 2006. Use of food resources by the fish fauna of a small reservoir (rio Jordão, Brazil) before and shortly after its filling. Neotropical Ichthyology 4(3):357-362.

Lowe-McConnell, R.H. 1999. Estudos ecológicos de comunidades de peixes tropicais. São Paulo, EDUSP. 535p.

Luz-Agostinho, K. D. G.; Bini, L. M.; Fugi, R.; Agostinho, A. A. \& JúLio, H. F. 2006. Food spectrum and trophic structure of the ichthyofauna of Corumbá reservoir, Paraná river Basin, Brazil. Neotropical Ichthyology 4(1):61-68

MacArthur, R. \& Levins, R. 1967. The University of Chicago The Limiting Similarity, Convergence, and Divergence of Coexisting Species. The American Naturalist 101(921):377-385.

Manna, L. R.; Rezende, C. F. \& Mazzoni, R. 2012. Plasticity in the diet of Astyanax taeniatus in a coastal stream from south-east Brazil. Brazilian Journal of Biology 72(4):919-928.

Margalef, R. 1983. Limnología. Barcelona, Ediciones Omega. 1010p.

Mazzoni, R. \& Rezende, C. F. 2003. Seasonal diet shift in a Tetragonopterinae (Osteichthyes, Characidae) from the Ubatiba River, RJ, Brazil. Brazilian Journal of Biology 63(1):69-74.

McCann, K. S.; Rasmussen, J. B. \& Umbanhowar, J. 2005. The dynamics of spatially coupled food webs. Ecology Letters 8(5):513-523.

Moraes, M.; Rezende, C. F. \& Mazzoni, R. 2013. Feeding ecology of stream-dwelling Characidae (Osteichthyes : Characiformes) from the upper Tocantins River, Brazil. Zoologia 30(6):645-651.

Nomura, H. 1975. Alimentação de três espécies do gênero Astyanax Baird and Girard, 1854 (Osteichthyes, Characidae) no rio Mogi Guaçu, SP. Revista Brasileira de Biologia 35:595-614.

Novakowski, G. C.; Hahn, N. S. \& Fugi, R. 2008. Diet seasonality and food overlap of the fish assemblage in a pantanal pound. Neotropical Ichthyology 6:567-576.

Peiró, D. F. \& Alves, R. DA G. 2006. Insetos aquáticos associados a macrófitas da região litoral da represa do Ribeirão das Anhumas ( município de Américo Brasiliense, São Paulo, Brasil ). Biota Neotropica 6(2):1-9. 
Pelicice, F. M. \& Agostinho, A. A. 2006. Feeding ecology of fishes associated with Egeria spp. patches in a tropical reservoir, Brazil. Ecology of Freshwater Fish 15(1):10-19.

Peretti, D. \& Andrian, I. D. F. 2004. Trophic structure of fish assemblages in five permanent lagoons of the high Paraná River floodplain, Brazil. Environmental Biology of Fishes 71:95-103.

2008. Feeding and morphological analysis of the digestive tract of four species of fish (Astyanax altiparanae, Parauchenipterus galeatus, Serrasalmus marginatus and Hoplias aff. malabaricus) from the upper Paraná River floodplain, Brazil. Brazilian Journal of Biology 68(3):671-679.

Pianka, E. R. 1974. Niche overlap and diffuse competition. Proceedings of the National Academy of Sciences 71(5):2141-2145.

R CORE TEAm. 2013. R: A language and environment for statistical computing. R Foundation for Statistical Computing, Vienna, Austria. Available at $<$ http://www.R-project.org/>.

Santos, L. N.; AraúJo, F. G. \& Brotto, D. S. 2008. Artificial structures as tools for fish habitat rehabilitation in a Neotropical reservoir. Aquatic Conservation 18:896-908.

Scheffer, M. \& CARpenter, S. R. 2003. Catastrophic regime shifts in ecosystems : linking theory to observation. Trends in Ecology \& Evolution 18(12):648-656.

Silva, M. R.; Fugi, R.; Carniatto, N. \& Ganassin, M. J. M. 2014. Importance of allochthonous resource in the diet of Astyanax aff. fasciatus (Osteichthyes : Characidae) in streams: a longitudinal approach. Biota Neotropica 14(3):1-10.

Silva-Camacho, D. D. S.; Santos, J. N. D. S.; Gomes, R. D. S. \& Araújo, F. G. 2014. Ecomorphological relationships among four Characiformes fish species in a tropical reservoir in South-eastern Brazil. Zoologia 31(1):28-34.
Suzuki, H. I.; Bulla, C. K.; Agostinho, A. A. \& Gomes, L. C. 2005. Estratégias reprodutivas de assembléias de peixes em reservatórios. In: Rodrigues, L.; Thomaz, S. M.; Agostinho, A. A. \& Gomes, L. C. eds. Biocenose em reservatórios: padrões espaciais e temporais. São Carlos, RIMA, p. 223-236.

Trivinho-Strixino, S. \& Strixino, G. 1993. Estrutura da comunidade de insetos aquáticos associados à Pontederia lanceolata Nuttal. Revista Brasileira de Biologia 53:103-111.

Uehara, W.; Albieri, R. J. \& Araújo, F. G. 2015. Structure of fish assemblages in seven tropical reservoirs in southeastern Brazil during the rainy season; what matters: physico-chemical or hydrological connectivity influences? Journal of Applied Ichthyology 31:10341042.

Uieda, V. S.; Buzzato, P. \& Kikuchi, R. M. 1997. Partilha de recursos alimentares em peixes em um riacho de serra do Sudeste do Brasil. Anais da Academia Brasileira de Ciências 69(2):243-252.

Vidotto-Magnoni, A. P. \& Carvalho, E. D. 2009. Aquatic insects as the main food resource of fish the community in a Neotropical reservoir. Neotropical Ichthyology 7(4):701-708.

Vilella, F. S.; Becker, F. G. \& Hartz, S. M. 2002. Diet of Astyanax species (Teleostei, Characidae) in an Atlantic Forest River in Southern Brazil. Brazilian Archives of Biology and Technology 45(2):223-232.

Windell, J. T. 1971. Food analysis and rate of digestion. In: Ricker, W. E. ed. Methods for Assessment of fish production in fresh waters. Oxford, Blackwell, p. 215-226.

Wolff, L. L.; AbilhoA, V.; Rios, F. S. \& Donatti, L. 2009. Spatial, seasonal and ontogenetic variation in the diet of Astyanax aff. fasciatus (Ostariophysi: Characidae) in an Atlantic Forest river, Southern Brazil. Neotropical Ichthyology 7(2):257-266.

Xu, J.; Wen, Z.; Gong, Z.; Zhang, M.; Xie, P. \& Hansson, L. 2012. Seasonal trophic niche shift and cascading effect of a generalist predator fish. PloS One 7(2):1-9. 